
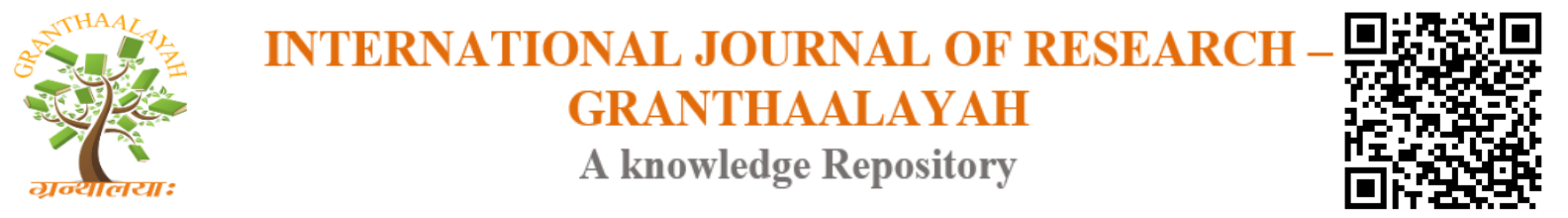

Science

\title{
FARMERS KNOWLEDGE ON INTERGRATED PEST MANAGEMENT IN CUCURBIT PRODUCTION
}

\author{
Christopher L Materu ${ }^{* 1}$, Essau W. Losujaki ${ }^{2}$, Irsyadi Zain ${ }^{3}$, Betty Chalamila 4 \\ ${ }^{*} 1,2,3,4$ P O Box 6226, Dar Es Salaam Tanzania
}

\begin{abstract}
It is estimated that more than $50 \%$ of the crop loss is due to pest infestation. Assessment of farmers' knowledge on Integrated Pest Management and pesticides use to manage threat pests, their safe use in cucurbit production was carried out using a semi-structured questionnaire. Results showed that cucurbit growers were categorized as youth 5\% (20-30 years, 31-40 middle age and 41-50 years were considered as old age growers. More than $90 \%$ of the growers use pesticides from Agro Input suppliers for managing different pests. Respondents identified aphids as a major pest represent $40 \%$ followed by leaf feeding pest $20 \%$, fruit flies represent $15 \%$ and the least was weeds $10 \% .95 \%$ of the interviewed growers were aware on negative side effect from pesticide use both to human and environment. Less than $40 \%$ of the respondents use protective gears during pesticide application. About $30 \%$ of the growers attended short course training on IPM through Farmer Field Schools. Despite of training on IPM none of them new insect identification, monitoring, biological control agents and other pollinators apart from bees. This study showed there is a need to train vegetable growers on importance of insect monitoring, biological control agent in cucurbit production.
\end{abstract}

Keywords: Cucurbit Growers; Knowledge; Pesticide; Integrated Pest Management (IPM).

Cite This Article: Christopher L Materu, Essau W. Losujaki, Irsyadi Zain, and Betty Chalamila. (2018). "FARMERS KNOWLEDGE ON INTERGRATED PEST MANAGEMENT IN CUCURBIT PRODUCTION." International Journal of Research - Granthaalayah, 6(12), 70-76. https://doi.org/10.29121/granthaalayah.v6.i12.2018.1078.

\section{Introduction}

Vegetables and fruits production in the country is increasing though increasing of insect pressure and climate change can cause more than $50 \%$ crop loss. Integrated pest management (IPM) is an environmental friendly approach for managing threat pests in cucurbits as it combines different practices for managing threat pests not only in cucurbits but also in other fruits and vegetable crops (Dhawan et al., 2010; Kabir and Rainis, 2012).

Excessive use of agricultural chemicals, including fertilizers and pesticides, has caused insect population build up, resistance, killing of non-target insects as well as pollute environment 
(George, 2009). Sustainable control measures of threat pests need information on life cycle, type of damage and stage of damage is very important. Despite of farmers training through farmer Field Schools but still they are not aware on wide range application of IPM technologies. Poor extension services justify need for farmers training on use of IPM as a sustainable control strategies for managing different pest species in cucurbit production.

Application of IPM programs depends on involvement of growers and other stakeholders from the initial stages of the project development (Asiabaka, 2002). Establishment of IPM groups ie FFS whereby growers has a room to apply his existing knowledge is mostly encouraged. Grower's awareness of a problem is the process of adopting a new technology. Testing of new IPM innovation under cucurbit field plots is an important step to adopt new technologies. Poor adoption of a new agricultural innovations justifies that effort to involve farmers in project implementations are not enough. The choice to adopt an innovation is regarded as an outcome of a series of influences exerted by forces of change on the behavior of the decision maker through time (Lionberger, 1968).

The emphasis is to build on capacity to cucurbit growers to proper problem identification.

Cucurbits are reported to be infested by a good number of pests and diseases which affect productivity. Stripped cucurbit beetle, Aphids and Melon fly are considered as a threat pests which affect yield quality and quantity. Melon fly or Dacus sp is an alien species introduced in the country accidentally and has indirect economic importance from restrictions imposed by fruits and vegetable importers. The adult female lay eggs developed into larval which feeds on fruits. Mature infested fruits drop. Furthermore, the larval tunnels provide entry points for secondary diseases including bacteria and fungi that cause the fruit to rot (Lall, 1975).

Studies on IPM in cucurbits production are limited and no research has been conducted to assess farmers knowledge in cucurbit production in Tanzania. The study aim to evaluate farmers awareness on IPM strategies in cucurbit production. Research findings will explain the most the important factors affecting knowledge of integrated management of threat pests in cucurbits and recommends suitable IPM strategies.

\section{Materials and Methods}

\subsection{Study Area and Sample Selection}

The study was conducted in Chekelei village situated in Tanga region. Geographical location of the area is $410 \mathrm{msl}$ located at $\mathrm{S} 04^{\circ} 59^{\prime} 21.9^{\prime \prime} \mathrm{E} 38^{\circ} 18^{\prime} 50.2^{\prime \prime}$.

\subsection{Questionnaire and Data Collection}

A structured questionnaire was developed for the survey based on information to be collected. Developed questionnaire was administered to 100 cucurbit growers from the selected area.

Questions were targeting to explore information about cucurbit pest management, demographic and economic variables, including age, education, experience in farming, experience in cucurbit 
farming, Cucurbit land area, yield, farm income, cucurbit farm income. The questionnaire was administered through face-to-face interviews with the farmers. The interviews were conducted using local language (Swahili) for smooth running of the dialogue.

\subsection{Data Analysis}

Data collected were analyzed using computer programme descriptive statistics (frequencies, percentages, means, and standard deviations) to develop graphs related to the objective, i.e., age, number of family members, farming experience, experience in cucurbit farming, farm area, mean cucurbit yield, annual income from cucurbits production, social participation and participation in extension activities

\section{Results}

\subsection{Cucurbit farmers' Demographic and Economic Profile}

Mean age of the respondents was categorized as 25\% (21-40), 50\% (41-60) and .25\% (61-80) years' old $40 \%$ of the population completed standards seven able to read and write). Furthermore more than $80 \%$ were experience in agricultural activities and side effects which caused by pesticides. (Figure 1).

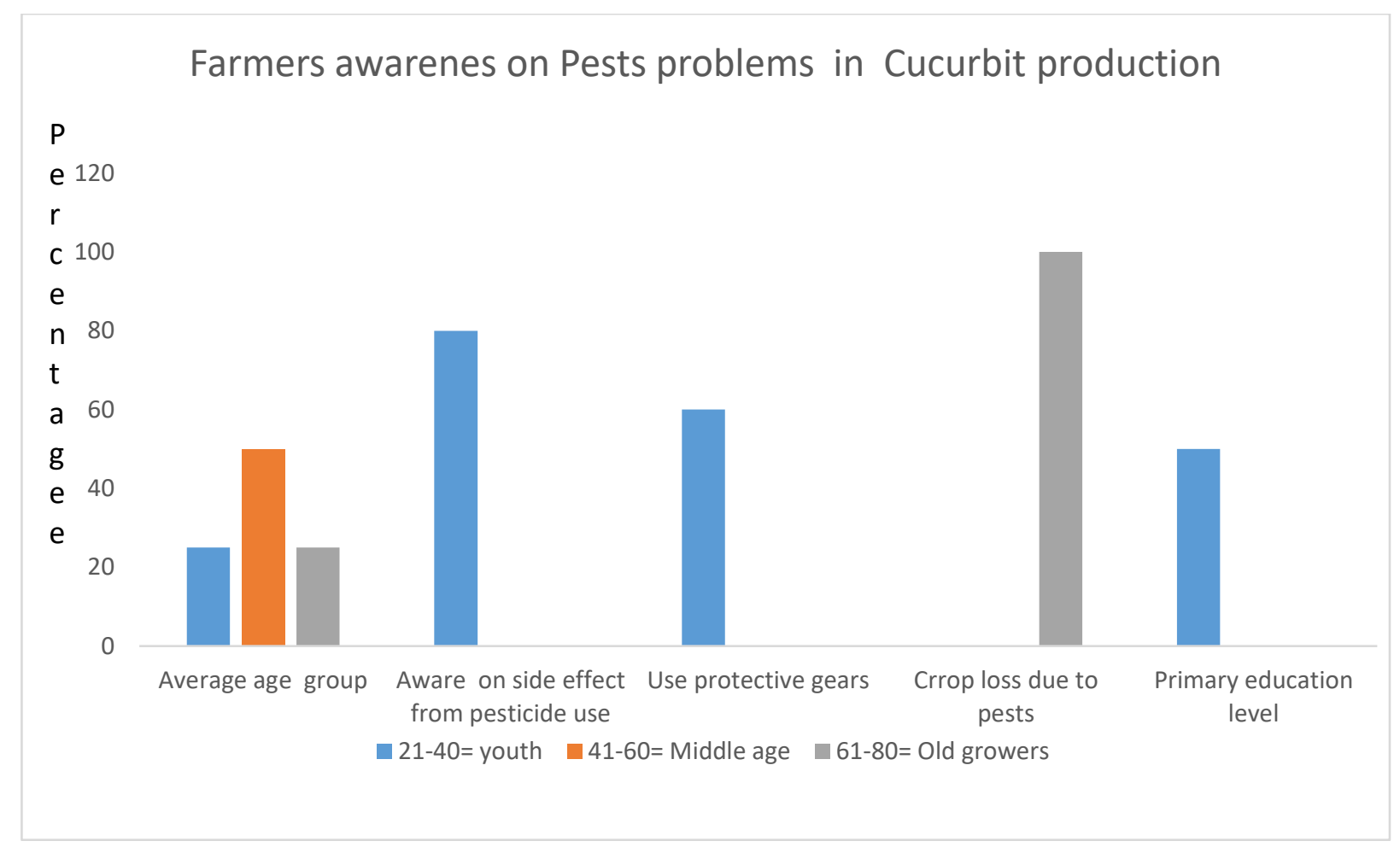

Figure 1: Farmers awareness on threat pests in cucurbit production

Growers identified aphid as a problem was 40\%, leaf feeding insects 20\%, fruit flies and Tuta absoluta were equally represented at $15 \%$ and the least was weeds $10 \%$ (Figure 2) 


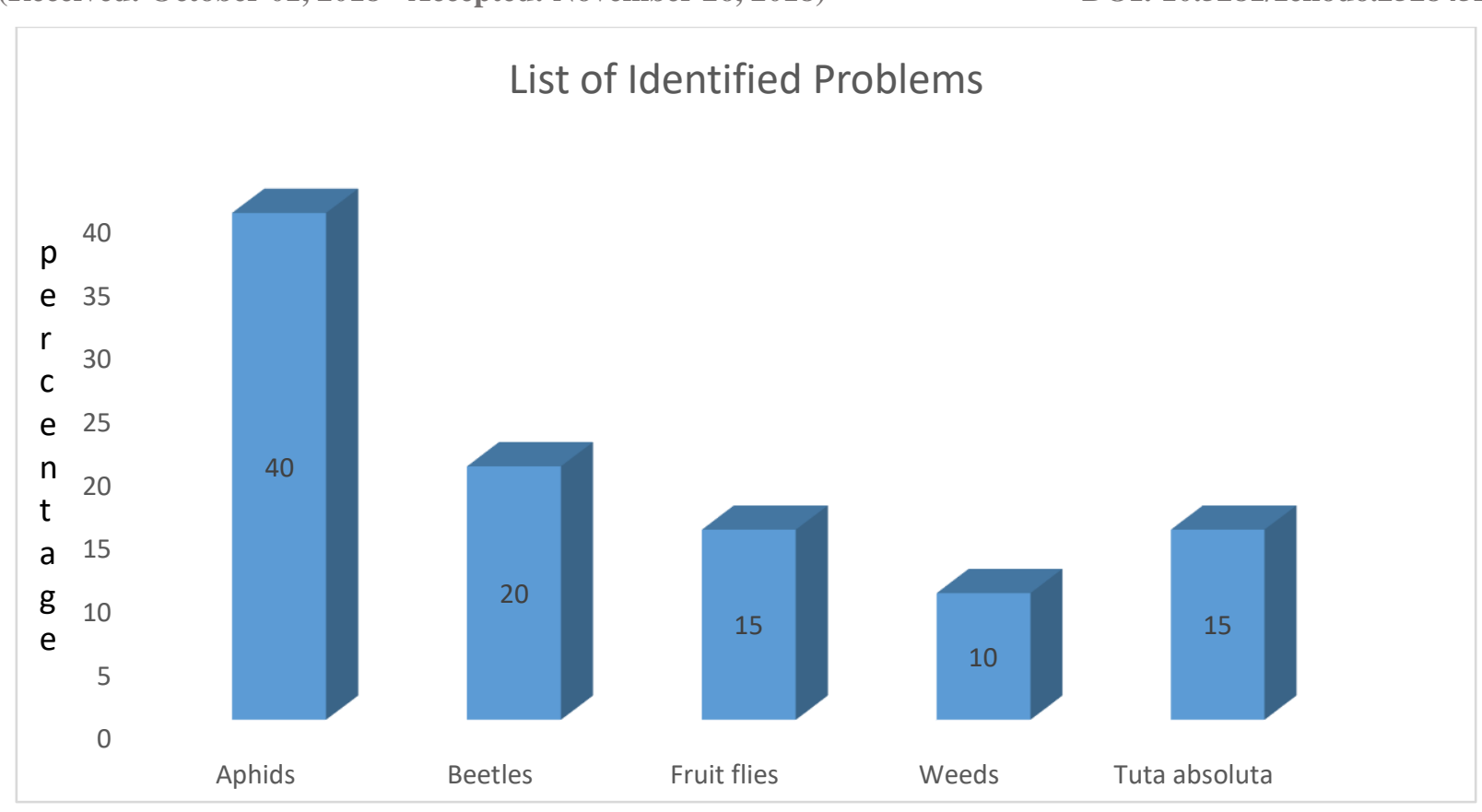

Figure 2: List of common pest identified by cucurbit growers

Lack of knowledge $20 \%$ spraying interval was reported as a major problem as majority sprays every after 7. Similarly 14 days spraying interval was represented by $60 \%$ of the respondents Majority of farmers use improved seeds and fertilizers but none of them mentioned use of biological control or non-chemical control methods, Furthermore lack of monitoring tools $60 \%$ and lack of common understanding lead to frequent sprays compared to the mount recommended by manufactures (Figure 3).

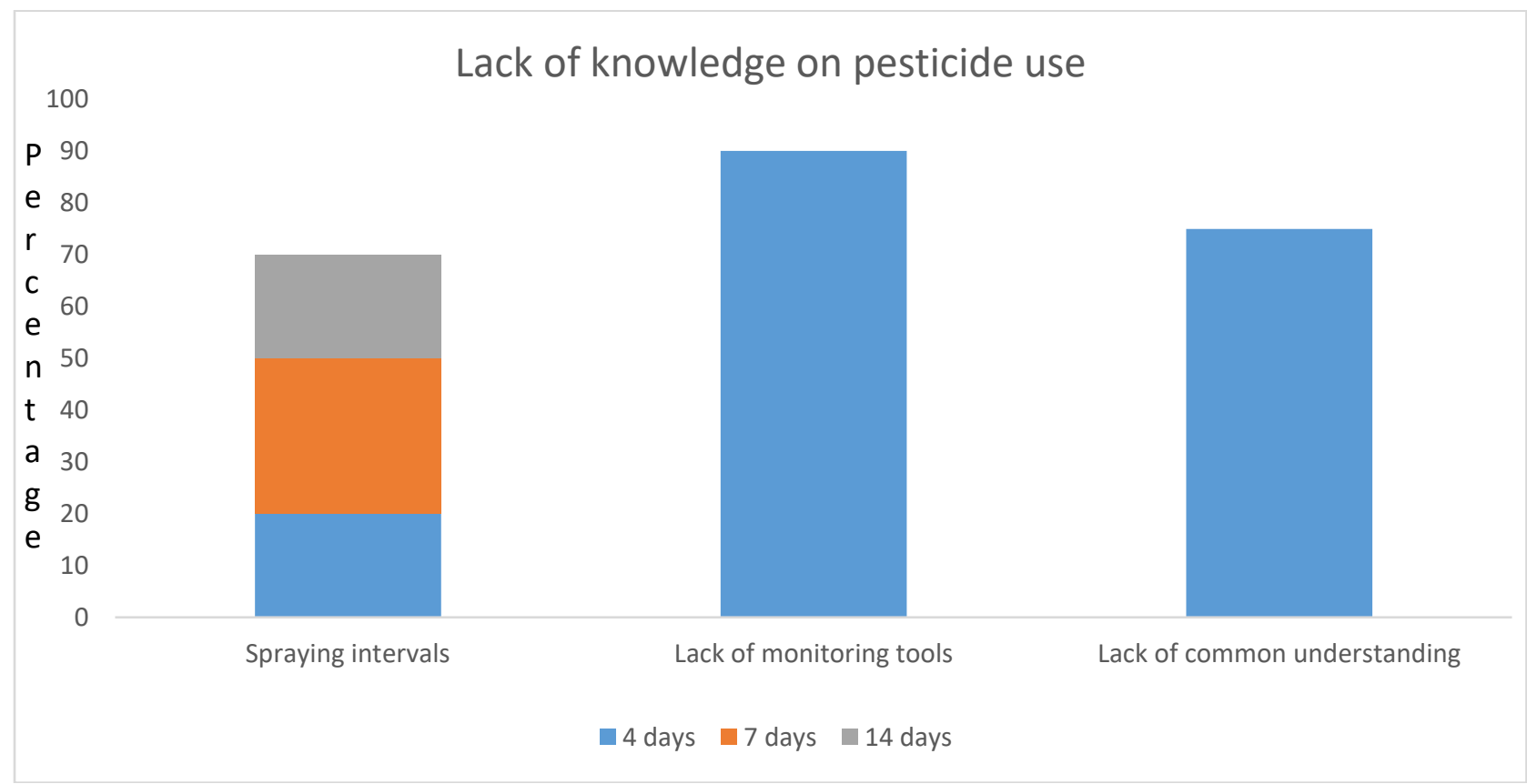

Figure 3: Lack of knowledge on sustainable pest management 


\section{Adoption of IPM Technologies}

Youth and aged people were $5 \%$ of the responded, middle age were more than $80 \%$ showing energetic people are involved in agricultural productivity. Furthermore, $40 \%$ of the respondents were aware on IPM and 30\% attended IPM training through Farmer Field Schools. 25\% of the respondent showed that extension services was one of the major constraint on adopting IPM technologies (Figure 4)

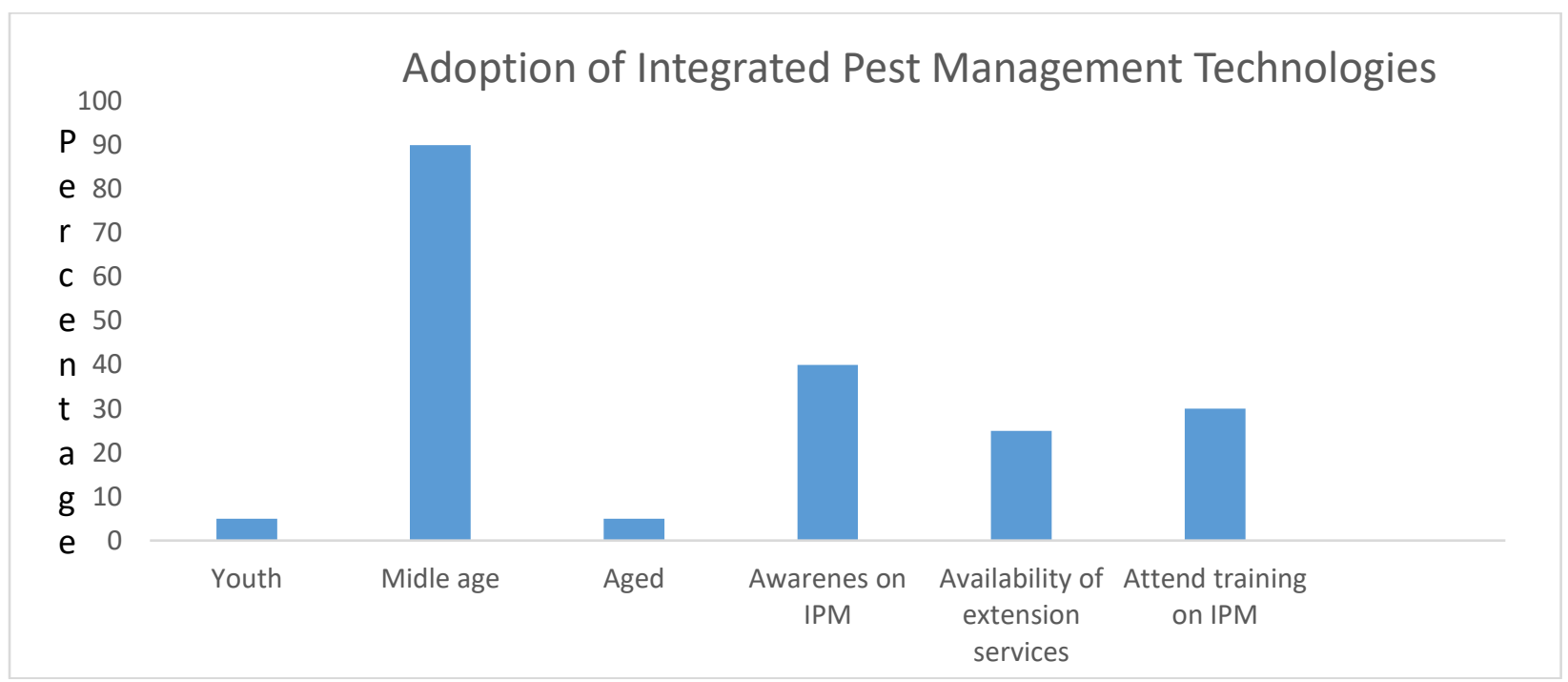

Figure 4: Factors affecting adoption of IPM technologies on cucurbit production

\section{Discussion}

\section{Respondent Characteristics}

Farmers from the selected area were characterized as smallholder farmers categorized into youth, middle age and older farmers. Youth group was considered as young generation attend ordinary level of education while middle age was considered as productive group. Aged group was considered as elder farmers which need support from the house hold. Farmers from the selected area decide to grow vegetable as they are short term crops and they can generate more income (Geist and Byers, 2017)

\section{Lack of knowledge on Pest Identification and Pesticide Use}

Their existing practice and knowledge regarding identifying different pest species, appropriate time for pesticide application was very low. None of the growers use organic product, biological control for managing threat pests. Furthermore, majority of the cucurbit growers were aware on side effects resulted from excessive pesticide use still they are relying on the similar method due to lack of knowledge (Asgarinya, 2010). Participants were asked to show amount of pesticide use for managing different pest species and it was found that amount differ from one grower to another similarly number of applications. This results into an excessive number of application when compared to manufactures recommendations

\section{Inadequate Extension Services}

Farmers showed little access to public extension service was inadequate to provide sufficient service. However, it was recommended that improve of an extension service will facilitate to 
enhance Farmers Field Schools approach. By doing so it will simplify IPM application through use of FFS. Participatory IPM and FFS approach under cucurbit growing areas can provide a better learning process hence increase cucurbit productivity from the identified areas (Bartlett, 2005; Drlik et al., 2001; Pinero, 2015).

Furthermore, the National plant protection policy (NPP) emphasis on use of extension staff to facilitate technology transfer to cucurbit farms and adoption of new innovative ideas. (Hammond, 2006). Adequate extension service will emphasis on use of biological control agents under farmers fields (Speight and Evans. 2004). Good extension services will also facilitate on IPM awareness promotion as well as training programmes that will demonstrate importance of vegetables for human health (Fernandez, et al., 1994; Mauceri et al., 2005).

\section{Lack of Pest Monitoring Tools in Cucurbit Growing Areas}

An effective integrated strategy for pest management in cucurbit is therefore affected by pest population monitoring. Farmers training programs that disseminate recent research results to the community. The current pest management still relies heavily on chemical pesticide use to reduce pest population pressures. It was agreed that lack of effective commercially monitoring tools, or available biological control agents for management of common pests identified has resulted into an excessive pesticide use (Povellato and Scorzelli, 2006; Mariano \& Fleming, 2012).

\section{Conclusions}

The collected information from cucurbit growers provides a better understanding on common pest in cucurbits production and their mitigation measures. Integrated Pest Management knowledge of common pests in cucurbits production is needed for sustainable productivity. Some farmers showed they had adequate knowledge about the impact of threat and pesticide use on cucurbits yield quantity as well as quality. Furthermore, majority of growers completed standard seven leaver able to read different instructions on pesticide use. Furthermore, they own mobile phones for easier communication. Farmers need training in integrated pest management strategies to ensure sustainable cucurbit production, as there is still an opportunity to improve their knowledge for sustainable cucurbit production.

\section{References}

[1] Asgarinya, S. 2010. Traditional agriculture of farmers because of lack of sufficient knowledge

[2] of modern techniques. IRNA.

[3] Asiabaka, C. (2002). Promoting Sustainable Extension Approach: Farmer Field School (FFS) and Its Role in Sustainable Agriculture Development in African. Department of Agricultural Economic and Extension, Federal University of Technology P.M.B, Owerri, Nigeria. Retrieved Jun 182008 from http://www.codesria.org/.

[4] Bartlett, A. (2005). Farmer Field Schools to Promote Integrated Pest Management in Asia: The FAO Experience. Workshop on Scaling Up Case Studies in Agriculture. International Rice Research Institute.16-18 August 2005. Bangkok. Retrieved Jun 102008 from http:// www.comunityipm.org/

[5] Geist, L., and P. L.Byers. 2017. MU Extension and partners grow knowledge among Hmong farmers. University of Missouri Extension. (https://extension2.missouri.edu/news/mu-extensionand-partners-grow-knowledge-among-hmong-farmers-3127) (verified 18 May 2018) 
[6] Hammond, C. M., E. C.Luschei , C. M. Boerboom, and P. J. Nowak, 2006. Adoption of Integrated pest management tactics by Wisconsin farmers Weed Technol $20: 756-767$

[7] Lionberger, M.F. (1968). Adoption of New Ideas and Practices.

[8] Iowa State University.

[9] George, D. 2009. Current Status of Crop Biotechnology in Africa. Pages 360-382 in N. Ferry

[10] and A. M. R. Gatehouse, editors. Environmental Impact of Genetically Modified Crops. CABI Publishing, Wallingford.

[11] Dhawan, A. K., Jindal, V., \& Dhaliwal, G. S. (2010). Insect pest problems and crop losses: Changing trends. Indian Journal of Ecology, 37(1), 1-7

[12] Drlik, T., W. Olkowski, H. Olkowski, and S. Daar. 2001. IPM for Schools: A How-To Manual.

[13] Bio-Integral Resource Center.

[14] Fernandez-Cornejo, J., Beach, E. D., \& Huang, W. Y. (1994). The adoption of IPM techniques by vegetable growers in Florida, Michigan and Texas. Journal of Agricultural and Applied Economics, 26(1), 158-172.

[15] Kabir, M. H., \& Rainis, R. (2012). Farmers' perception on the adverse effects of pesticide on environment: A case of Bangladesh. International Journal of Sustainable Agriculture, 4(2), 25-32.

[16] Mariano, M. J., Villano, R., \& Fleming, E. (2012). Factors influencing farmers' adoption of modern rice technologies and good management practices in the Philippines. Agricultural System, 110, 4153

[17] Mauceri, M., Alwang, J., Norton, G., \& Barrera, V. (2005). Adoption of integrated pest management technologies: A case study of Potato farmers in Carchi, Ecuador. Selected paper prepared for presenting at the American Agricultural Economics Association Annual Meeting, providence, Rhode Island, July 24-27.

[18] Lall, B. S. 1975. Studies on the Biology and Control of Fruit Fly, Dacus cucurbitae COQ. Pesticides. 9(10): 31-36.

[19] Piñero, J. C., J.Quinn P. L. Byers P. D. Miller, T. Baker, and D. Trinklein. 2015. Knowledge and Use of Integrated Pest Management by Underserved Producers in Missouri and the Role of Extension J. Ext. [On-line], 53. Article 3RIB3. (http://www.joe.org/joe/2015june/rb3.php)

[20] Povellato, A., Scorzelli, D. (2006). The Farm Advisory System: A Challenge for the Implementation of Cross Compliance. Deliverable D14 of the CC Network Project.

[21] Speight, M. R., and H. F. Evans. 2004. Integrated Pest Management Principles. Elsevier Ltd.

[22] Farmers' knowledge of IPM: A Case Study in the Zanjan Province in Iran (Karamidehkordi, E. and Hashemi, A.)

*Corresponding author.

E-mail address: chrismateru@yahoo.com/essau.losujaki@gmail.com/chaspaul2000@yahoo.com/ bettychalamila@yahoo.com 